\title{
Which Economics? Which Economies?
}

\section{A Comment on "What Is Wrong with the West's Economies?" by Edmund Phelps}

\author{
Heinz D. Kurz ${ }^{1}$
}

Received: 2 May 2016/Accepted: 6 May 2016/Published online: 30 September 2016

(C) The Author(s) 2016. This article is published with open access at Springerlink.com

\begin{abstract}
It is argued that the problems affecting our societies at present are not so much the result of a mysterious disappearance of inventiveness and imagination, as Phelps deplores. It is rather the dramatic change of the socio-economic order propelled by the neoliberal ideology that captured the minds of many people and politicians. This led to a de-regulation of financial markets and a policy of austerity, which triggered the "Great Recession" and stifled innovation. There is also the problem of a mismatch between our measurement devices and what is to be measured in a world of bits and bytes. With the firm establishment and growth of $R \& D \& I$ in all Western economies the talk about a declining innovativeness ought to be received with suspicion. New materials and rare earths, biotechnology, further advances in ICT and what is called the fourth industrial revolution based on cyber-physical systems can be expected to have an important impact on economic performance.
\end{abstract}

Keywords Adam Smith - Classical economics · Financial crisis · Innovation · Joseph A. Schumpeter · Technical progress

JEL classification A13 $\cdot$ B12 $\cdot$ B13 $\cdot$ B31 $\cdot$ E44 $\cdot$ O31 $\cdot$ O47

\section{Introduction}

In a paper published in the New York Review of Books (2015, vol. 6, no. 13), reprinted as Phelps (2016) in Homo Oeconomicus, Edmund Phelps asks: "What is wrong with the economies of the West-and with economics?" and adds: "It

Heinz D. Kurz

heinz.kurz@uni-graz.at

1 The Graz Schumpeter Centre, University of Graz, Universitätsstraße 15, Resowi FE, 8010 Graz, Austria 
depends on whether we are talking about the good or the just" (p. 1). I surmise instead that it depends first and foremost on which kind of economics we are talking about and partly also about which economies of the West. Phelps appears to imply that there is only one kind of economics, not several, and that Western economies all exhibit largely the same performance. Yet, while there is a mainstream in economics, there is clearly no unite de doctrine, and while there are parallels among several Western economies, there is no unité de développement. Is Phelps' view stricken by a lack of differentiation both on a theoretical and an empirical level?

Phelps deplores that "Our prevailing political economy is blind to the very concept of inclusion; it does not map out any remedy for the deficiency" (p. 4). By this he means that today's economics is exclusively concerned with "consuming goods and having leisure" and disregards the fact that "many people have long felt the desire to do something with their lives" above and beyond what economists argue they are doing. This is only partly true, and exceptions could easily be invoked. But I am not so much interested in this issue as in what or whom he blames for the neglect, that is, "classical economics," which is said to be concerned with a rather "pitiful sort of economy" (p. 6). "In the classical model," he opines, "no one is trying to think up something new ... and no one is attempting to create it. ... The economy is mechanical, robotic. The crops may be growing, but there is no personal growth.” (p. 7). Surprisingly, he takes Joseph A. Schumpeter as a representative of this view: "Joseph Schumpeter portrays 'innovation' as produced by hard-driving entrepreneurs who make 'obvious' applications of discoveries occurring outside the nation's economy - as if the economy's central participants possessed no imagination whatever" (p. 7). Phelps concludes: "Such classical models are basic to today's standard economics. This economics, despite its sophistication in some respects, makes no room for economies in which people are imagining new products and using their creativity to build them. What is most fundamentally 'wrong with economics' is that it takes such an economy to be the norm-to be 'as good as it gets.' The cost is that elements of the Western economies are becoming products of this basically classical economics, which has little place for creativity and imagination" (p. 7).

These statements I find difficult to sustain. The idea that economies are shaped in the image of what some economists think they are, appears to me to strongly exaggerate the importance of the latter. (I will talk about exceptions to this below.) Economists are able to capture the minds of some people, and the policies they recommend, if realized, do have real effects. But not infrequently these effects raise doubts about the correctness of the economic analysis underlying the policy. Had (mainstream) economists managed to shape the economy according to their views of it, such discrepancies between expected and actual effects of a policy should have become more and more narrow. This, however, does not seem to be the case.

More important from the perspective taken in this note, Phelps portrays "classical" and "Schumpeterian" economics in a way that amounts to a travesty of facts. In this note I indicate in which respects I think his account is misleading, and why, and what in my view provides a better perspective on some of the important issues raised by him. Section 2 deals critically with his concept of "classical economics" and Sect. 3 with his view of "Schumpeterian economics". Section 4 
has a glance at the empirical evidence and the question of whether the received measurement devices at our disposal are appropriate in regard to the novel phenomena we are confronted with. Section 5 concludes.

\section{Classical Economics on Development and Growth}

Has Phelps fallen victim to John Maynard Keynes' misleading concept of “classical economics" in The General Theory (Keynes 1936)? Keynes' knowledge of the writings of Smith and Ricardo was poor; he relied essentially on the judgement Marshall had passed on them in the Principles, interpreting them as precursors of the marginalist doctrine. Indeed, Keynes' points of reference were essentially representatives of the neoclassical doctrine: Alfred Marshall and Arthur Cecil Pigou. These had advocated "Say's law" according to which every act of saving will swiftly lead to an act of investment of the same magnitude, so that aggregate effective demand can never persistently constrain output as a whole and employment. Since Ricardo in his controversy with Malthus about the impossibility of a "general glut" of commodities also insisted that acts of saving (and thus leakages of effective demand) will be met by acts of investment (and thus injections of effective demand), Keynes took Ricardo to imply that the economic system incessantly tends towards, or gravitates around, the full employment of labour.

Alas, things are invariably more complicated. In the classical economists "Say's law" was meant to apply to capitalistically produced commodities only, and thus not to labour power, which is not so produced. Therefore, the alleged "law" did not apply to what was later called the "labour market", a concept elaborated by the marginalist authors, who subsumed this market under the "law" (see Kurz 2016). Keynes' focus on the employment issue made him confound the two different concepts of the law and also made him ignore a fundamental difference between the classical and the marginalist approaches to the theory of value and distribution. As Keynes' younger colleague Piero Sraffa, whom he respected a great deal, showed, the classical economists did not treat wages and profits symmetrically in terms of the demand for and supply of a factor "labour" and a factor "capital". In the theory of value and distribution they rather took the real wage rate (or the share of wages) as given and determined the rate (and share) of profits residually in terms of the "surplus product" left after all used up means of production and the real wages in the support of workers had been deducted from gross output levels. (They determined the level of wages in another part of their analyses - the part concerned with capital accumulation, population growth, the scarcity of natural resources and different forms of technical progress.) This surplus theory of profits determines the rate of profits in a given place and at a given time in terms of given output levels and given wages. Competitive conditions force agents to behave in a cost-minimizing way and make them choose methods of production from among available alternatives that maximize the general rate of profits. A higher (lower) level of real wages typically changes the technique chosen and implies a lower (higher) rate of profits. This is Ricardo's fundamental "law of distribution". 
In this perspective workers and the proprietors of "capital" are not paid the marginal products of the respective factor services, not least because typically there are no smooth opportunities of substitution among them. More importantly, it is even unclear what "substitution" between "capital" and labour means vis-à-vis the heterogeneity of capital goods. Clearly, in long-period analysis, every atom of "capital" yields the same rate of profits, but since capital in whichever line of production typically consists of a set of various concrete capital goods, capital can only be conceptualised as a value magnitude, not as a physical one like labour of a particular skill or land of a particular quality. But what is the marginal product of a "little more" value capital, ceteris paribus? We may also ask: on what grounds can it be said that a larger rate of profits corresponding to a lower real wage rate is more (less) "just" than a lower rate of profits corresponding to a larger real wage rate? Clearly, one class would be better off to the detriment of some other class(es), but what is the general metric of justice that would allow one to assess changes in income (or wealth distribution)?

In the classical economists we do not encounter such a metric. What we encounter instead is their pronounced concern with economic development and the distribution of the fruits of economic growth. Adam Smith cared for the participation of the "labouring poor" in the wealth of a nation and therefore focused attention on capital accumulation and an ever deeper division of labour, which was seen to be accompanied by technical and organizational improvements and a rising labour productivity. The larger the rate of capital accumulation, the more rapid the growth of markets, the greater the scope for a further deepening of the division of labour, the quicker the growth in labour productivity, the higher the rate of profits spurring further capital accumulation, the more rapid the increase in the demand for hands, which, for a given reproductive behaviour, will result in an upward trend of real wages. This is the essence of Smith's doctrine of the unintended consequences of selfishness: capitalists, seeking to increase profits, trigger a socio-economic process that turns out to be beneficial also to workers in terms of a trickling down of the rising wealth of a nation to the lower classes of society. Smith makes it very clear that self-seeking behaviour generates (net) positive externalities only in a society that is well governed and that restrains as much as possible the dark sides of selfishness in terms of a country's constitution, its laws, institutions and regulatory framework. Not for nothing he spoke of political economy as perhaps the most important branch of the "science of the legislator", because it is meant to instruct the legislator about which commandments, prohibitions, norms and incentives can further the well-being of society at large.

From a Smithian perspective one may thus say that some of the difficulties that currently beset Western societies is to a considerable degree due to the perforation of the "protective belt" against socially harmful behaviour and schemes especially in financial markets. It is a consequence of deregulatory measures implemented under the spell of the neoliberal ideology. The effect was a dramatic increase in systemic risks. Sadly enough, in response to the financial turmoil and its implications for the real economy the protective belt has not been strengthened again to be able to successfully ward off the dangers associated with "financial innovations" that benefit the few to the detriment of the many. Smith stressed: "The 
obligation of building party walls, in order to prevent the communication of fire, is a violation of natural liberty, exactly of the same kind with the regulations of the banking trade which are here proposed" (WN II.ii.94).

Deregulation and financial innovations have brought about a banking system that is predominantly concerned with making profits in short-term financial transactions and no longer in financing long-term profitable investments. By paying huge salaries and bonuses to employees in the financial business, many bright young people have been prevented from seeking jobs in more productive sectors of the economy. Partly stimulated by governments, banks have channelled huge amounts of money unproductively into the housing and real estate sector, generating a huge bubble there. Under the impression of the slump and the failure of many firms to pay back their debts and of bankruptcies, banks and financial agencies are reluctant to provide credit for new firms and start-ups, which reduces the overall rate of innovation and decelerates the diffusion of new technologies in the economic system. It is my impression that Phelps underestimates the negative and lasting effects of the "neoliberal" ideology that has conquered large parts of economics like the Holy Inquisition had conquered Spain, to use Keynes' famous phrase (see Kurz 2010).

A key concept in Adam Smith's Wealth of Nations is what we nowadays call "dynamically increasing returns to scale" that are endogenous to the economy as a whole, and not just to single firms. Such an economy can hardly be called "mechanical, robotic". What Phelps appears to have in mind when speaking about the "classical" economists are in fact the marginalist or neoclassical ones, with Marshall and his Newton-inspired view of the economic world as one of its major spokesmen. ${ }^{1}$

Contrary to Phelps' contention, Smith made "room for economies in which people are imagining new products and using their creativity to build them." In a famous passage the Scotsman stressed:

Many improvements have been made by the ingenuity of the makers of the machines, when to make them became the business of a peculiar trade; and some by that of those who are called philosophers or men of speculation, whose trade it is, not to do any thing, but to observe every thing; and who, upon that account, are often capable of combining together the powers of the most distant and dissimilar objects. In the progress of society, philosophy or speculation becomes, like every other employment, the principal or sole trade and occupation of a particular class of citizens. (Smith 1976b,WN I.i.9; emphasis added)

Philosophy or speculation, i.e., science, percolates ever-more modern society and becomes the foundation of its material metabolism and surplus creation. Almost a quarter of a millennium prior to the invention of the term "knowledge society" Smith insisted that "the quantity of science" available to a society decides its

\footnotetext{
${ }^{1}$ It deserves to be noted, however, that Marshall cannot be reduced only to this vision. He actually wrote that "the Mecca of the economist lies in economic biology rather than in economic dynamics," with "dynamics" in this case denoting an approach more mechanistic (in the sense of Newton's astronomy) than evolutionary. If the "evolutionist" aspect of Marshall's work does not come up for discussion in much of economics, this is because today's mainstream economics sees the mechanical-not the biological—as of paramount importance.
} 
members' productivity and wealth (WN I.i.9). It is not so much the ingenuity and creativity of single individuals that matters, as Phelps seems to imply, it is an entire industry- $R \& D \& I$ : Research, Development and Innovation-that takes on the task of incessantly revolutionizing the methods of production and the world of commodities. An important concept in this regard is "systems of innovation" at the regional, national and international level-networks of scholars, engineers, technicians and firms, and their collaboration. With the establishment and growth of such a "trade", the process of generating "improvements" and innovations has been put on a firm basis and has become organised, systematic, market-oriented and sustainable. Smith deserves credit for having sensed the emergence of such a trade as early as the threshold of the Industrial Revolution.

It is interesting to note that Smith uses the combinatory metaphor to describe novelty: new economically useful knowledge derives from the combination of reconfigured bits of known particles of knowledge - a definition, which involves the path dependency of progress in knowledge. Interestingly, Schumpeter (1912) and several other economists after him adopted the metaphor; see most recently Weitzman (1998).

Phelps deplores that "In most of Western Europe, economic dynamism is now at lows not seen, I would judge, since the advent of dynamism in the nineteenth century. Imagining and creating new products has almost disappeared from the continent". He adds: "Growth there has stopped, and econometric estimates of the rate of homegrown innovation are generally small. The near disappearance of imaginative and creative activity has reduced indigenous innovation, contracted investment activity, and depressed the demand for labor" (p. 7). In view of the firm establishment and absolute and relative growth of the $R \& D \& I$ sector in Western Europe, this assessment ought to be received with suspicion. Phelps appears to allude to Robert J. Gordon's finding within conventional growth accounting that the annual growth rate of total factor productivity has declined from "abnormal" heights in the 1950s to long-run normal levels in recent decades. The question, however, is what we actually see, to use Phelps' term, and what we don't, employing the received devices of measuring economic performance. There is reason to presume that our measurement techniques, while tailored to a world of corn and iron, are bound to fare badly in a world of bits and bytes. Therefore, one ought to beware of premature judgements.

In a recent note, growth economist Paul Romer (2015) chastised many of his colleagues who are said to be still convinced to be able to treat scale effects due to nonrival ideas (such as new industrial devices) in terms of conventional Marshallian economics with the attention on price taking in perfectly competitive markets. He calls these people "traditionalists" and describes the challenge, as he sees it, which growth economics faces, as consisting of the following:

For the last two decades, growth theory has made no scientific progress toward a consensus. The challenge is how to model the scale effects introduced by nonrival ideas. Mobile telephony is the update to the pin factory, the demonstration that scale effects are too important to ignore. To accommodate them, many growth theorists have embraced monopolistic competition, but an 
influential group of traditionalists continues to support price taking with external increasing returns. (Romer 2015: 89)

The "pin factory" is, of course, a reference to Adam Smith's discussion of the division of labour and the scale effects that come with it. It is indeed a (frequently unconscious) return to the classical perspective on economic development and growth and an abandonment of the marginalist or neoclassical one that is characteristic feature of some of the contributions to what had been dubbed "new" or "endogenous" growth theory (see Kurz and Salvadori 1998). Unfortunately, the new perspective was embedded in an old analytical framework using macroeconomic production functions, as if genuine novelty and qualitative change could be represented by quantitative change, i.e., ever more of the same stuff. ${ }^{2}$ A characteristic feature of the process of modernization and socio-economic development is thus not captured at all: the fact that the cosmos of commodities is growing all the time, because the number of newly invented commodities exceeds that of displaced ones: we are confronted with an increasing heterogeneity of goods, means of production, types of labour etc. How could a one-good model possibly tell us something interesting about it?

Finally, a brief comment is apposite on Phelps' treatment of "imagination" as something that is invariably good, a universal blessing, like "creativity". In the Theory of Moral Sentiments, Adam Smith (1976a) dealt with imagination inter alia in the context of a discussion of "deception" and sees it as ambiguous from a moral point of view. He wrote: "The pleasure of wealth and greatness, when considered in this complex view, strike the imagination as something grand, and beautiful, and noble, of which the attainment is well worth all the toil and anxiety which we are so apt to bestow upon it." He added:

And it is well that nature imposes upon us in this manner. It is this deception which arouses and keeps in continual motion the industry of mankind. It is this which first prompted them ... to invent and improve all the sciences and arts, which ennoble and embellish human life; which have entirely changed the whole face of the globe ... (TMS: 303)

However, Smith insisted, certain "passions arise altogether from the imagination" (TMS: 78). Creativity and imagination, he stressed, can also be put at the service of evil motives. The continuing turbulences in the financial sector are to no small degree the result of new financial instruments, some of which appear to have been invented in order to fool ill-informed people. "Mean people", Smith stressed, can be expected to ruthlessly exploit the situation.

\footnotetext{
2 After having found out that one of his earlier formalisations of growth theory were incompatible with the nonrivalry of new industrial devices (new methods of production, etc.), Romer belittled his blunder by emphasizing that "it may seem a trifling matter in an area of theory that depends on so many other short cuts. After all, if one is going to do violence to the complexity of economic activity by assuming that there is an aggregate production function, how much more harm can it do to be sloppy about the difference between rival and nonrival goods?" (Romer 1994: 15-16) The answer clearly is that one ought to refrain from assuming a macroeconomic production function, which has never been shown to be the result of consistent aggregation across micro units of production.
} 
Such asymmetries permeate the Wealth of Nations and apply to large groups of people and even to entire classes of society. The worker is most in danger of being manipulated, Smith insists. Upon particular occasions his "clamour is animated, set on, and supported by his employers, not for his, but their own particular purposes"(WN I.xi.p.9). Merchants and master manufacturers are said to be possessed of a "superior knowledge of their own interest", which "is never exactly the same with that of the publick"; and who "have generally an interest to deceive and even to oppress the publick, and who accordingly have, upon many occasions, both deceived and oppressed it." (WN I.xi.p.10)

The massive change in the distribution of income and wealth reported by Tony Atkinson, Thomas Piketty and others can be interpreted in Smithian terms as reflecting to a considerable extent the impact of a change in economic policy, the tax system, social institutions and the incentive structure consequent upon the neoliberal campaign. With regard to the policy recommendations coming from business and moneyed men, Smith had warned, these "ought always to be listened to with great precaution, and ought never to be adopted till after having been long and carefully examined, not only with the most scrupulous, but with the most suspicious attention" (WN I.xi.p.10). Alas, his warnings had not been taken seriously, and there are no signs that things have changed much since 2007. The neoliberal ideology has captured the minds of many people and is still predominant amongst politicians.

\section{Schumpeter and "Creative Destruction"}

The picture Phelps draws of Schumpeter I find particularly unsatisfactory. I am almost inclined to say that the exact opposite of what he writes about the author of the Theory of Economic Development, first published in German in 1912, comes closer to the truth. A quick summary of Schumpeter's ideas is apposite.

The Austrian economist chooses Sir Isaac Newton's "Hypotheses non fingo" as the motto of his book. By this he wishes to say that he does not put forward hypotheses, but well-founded propositions. These are designed to complement Walras' theory of the circular flow by a dynamic theory of socio-economic development. In this way he seeks to overcome the "sea of darkness" that hides the law of motion of the capitalist economy from our eyes. Like the hero in his book, the entrepreneur, Schumpeter is an innovator whose work involves "creative destruction". He demolishes received ideas and theories, including those of some of his Viennese teachers. Walras' theory, he opines, is useful in understanding the hypothetical stationary state, but not the real world: innovations, the "realisation of new combinations" - are "the overwhelming fact in the economic history of the capitalist society" (1912: 159). Ironically, Schumpeter levelled the same kind of criticism at Walras that Phelps levels at Schumpeter. In fact, while conventional marginalist (neoclassical, Walrasian) theory is concerned with homo oeconomicus, anxious to optimally adjust to given circumstances (constraints), Schumpeter is concerned with homo faber, homo laborans or homo innovativus, incessantly 
seeking to overcome existing limitations and removing barriers in terms of new goods, new methods of production, new forms of organizing firms and so on.

Two aspects of Schumpeter's theory are of particular importance vis-à-vis Phelps' argument. The first concerns Schumpeter's conviction from the second (revised and abridged) edition of the Theory of Economic Development ([1926] 1934) onwards, and echoing ideas of the Russian economist Michal TuganBaranovsky and Schumpeter's fatherly friend Arthur Spiethoff, that there are long waves of economic development. Each of these is taken to be lasting for about 50 years, triggered by what were later called "basic innovations" or, more recently, "general purpose technologies". In contrast to incremental innovations they are non-incremental and tend to revolutionize the entire economy. According to some interpreters, many Western economies are currently experiencing the end of such a long wave. What from the Schumpeterian point of view is a phase in the normal development of the capitalist economy, with an upswing lurking around the corner, Phelps takes to be a sign of its secular decline. It would be interesting to know what he finds wrong with the Schumpeterian view.

The second aspect concerns the fact emphasized by Schumpeter that while the financial sector is of the utmost importance to the financing of investment needed in order to realize innovations, economic downturns may be aggravated and prolonged because of the instability of the finance industry. After the ball is over, so to speak, banks don't trust lenders and would-be lenders anymore and are unwilling to grant credits and finance investments. This stifles innovations and decelerates the rate of growth of productivity. Firms in many Western European countries currently experience banks' reticence to provide liquidity. With the "head quarter of the capitalist economy", as Schumpeter (1912: 276) called it, being paralyzed, so is the economy as a whole. Since with the hypertrophic growth of the financial sector and the huge profits that could be made there, also banks' attitude and the skills of their employees have changed. Many bankers have lost the capacity to form solid judgements on investment projects submitted to them, because they lack expert knowledge and a long-run orientation. They have become first and foremost speculators on financial markets and are no longer concerned with long-term productive investments. This appears to me to be a main problem at present.

Phelps asks the important question, whether economic development implies "progress"- a question that already bothered Schumpeter quite a bit. Schumpeter abstains from a definitive judgement and stresses that "Whether development leads to social wellbeing or social misery is decided by its concrete content." (1912: 492) In his view the "deepest sense" of development consists in providing new qualities and quantities of goods, which the capitalist machinery accomplishes most impressively. However, the unintended political, ecological, cultural and so on consequences of this success must not be underrated: they do have the power of pushing the system socially and culturally in new and possibly not very agreeable directions.

Both Smith and Schumpeter emphasized the institutional setup within which human action takes place. Institutions define the rules of the game in society and shape the incentive structure faced by economic agents. Does this structure favour productive activities that promote individual and social wellbeing or does it 
encourage unproductive ones, rent-seeking and the like, that favours a few individuals or groups to the detriment of the large majority? Does it lead to social conflicts, erode fairness and trust and promote corruption? In my view the change in income and wealth distribution constitutes a major threat to the foundations of civic society: the amassment of economic and political power in a few hands undermines democracy and meritocracy and leads us back to quasi-feudal and patrimonial conditions. If economic power gets more and more concentrated, an irreconcilable contradiction obtains between the democratic logic of "one voter one vote" and the market logic of "one Dollar one vote."

Globalization has benefited those who are possessed of resources (capital, skills etc.) and can participate in international markets to the detriment of those who cannot. By dismantling the welfare state and implementing a policy of austerity in the EU the lot of the losers of globalization has been further aggravated. This could, in principle, have been grist to the mills of the political left, but with a few exceptions it was not-neither in Europe nor in the United States, with a Republican candidate for presidency that gives rise to worst fears. In Europe the problem of mass migration triggered by the war President Bush junior had irresponsibly waged on Iraq and the consequent destabilization of the entire middle east has led to a shift in public discussion away from the distributive effects of globalization to the alleged "threat" posed by Syrian, Iraqi and other refugees. This played into the hands not of the political left, but the right, with nationalist and populist tendencies endangering the survival of the open society and the European project and deepening divisions within and between nations. These appear to me to be the real problems we are facing at present. The issue of "inclusion" ought to be seen in this context.

\section{Facts, Figures and the Future}

In this section I first provide some graphs showing the growth of labour and capital productivity in several countries for the manufacturing sector in the period 1995-2007 and for the economy as a whole in the period 1980-2011. ${ }^{3}$ Compared to the services sector the measurement problem in the manufacturing sector is arguably a great deal less serious.

Figure 1 shows that, with the exception of France, the growth rate of labour productivity in all countries covered does not exhibit a downward trend. In the majority of countries - China, USA, Great Britain, Germany and Japan-the trend was rather persistently and strongly upwards, while in Austria and Italy it was first slightly downwards and then slightly upwards again. The high and accelerating growth of labour productivity in China reflects the catching-up process that is taking place there. What is remarkable, however, is that in several major highly developed economies the growth of labour productivity increased and in several cases more than doubled, from around 2 per cent per year to 4,5 or even 6 per cent. There are

\footnotetext{
3 I am grateful to Marlies Schütz for having prepared the graphs.
} 


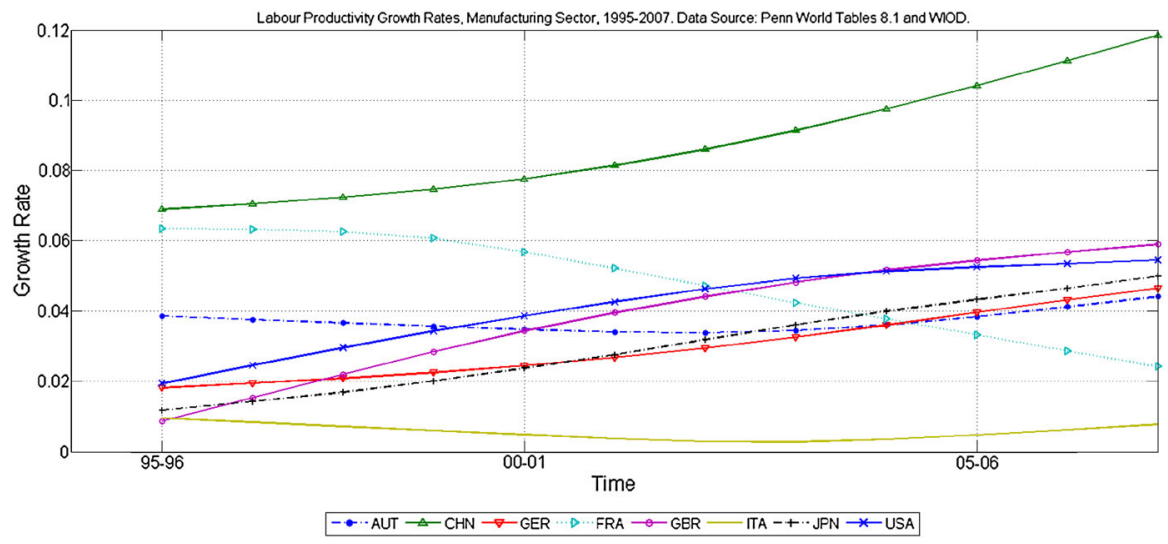

Fig. 1 Labour productivity growth in manufacturing

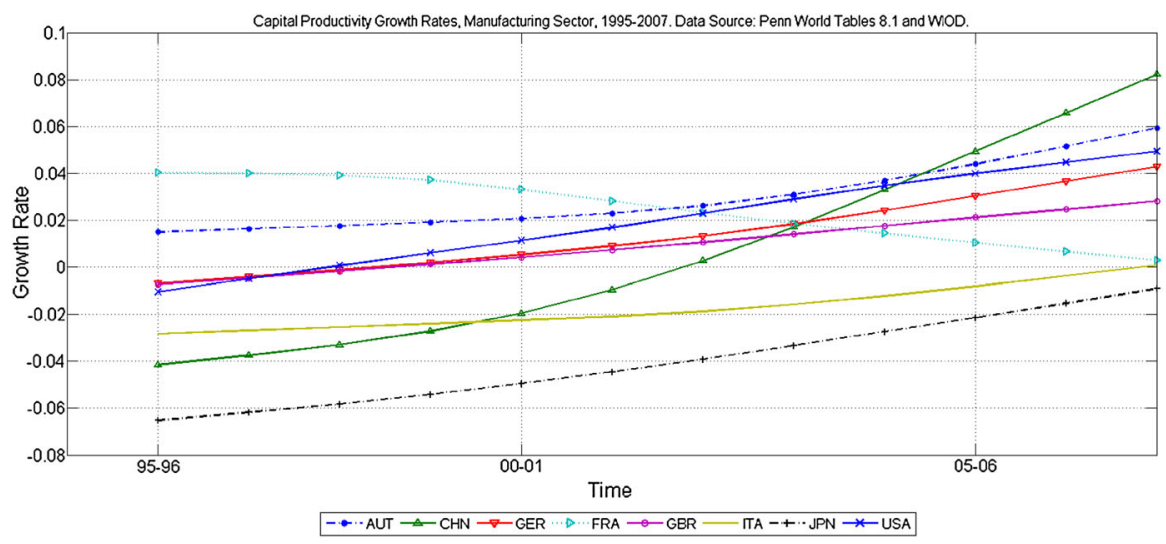

Fig. 2 Capital productivity growth in manufacturing

no signs of a deceleration of productivity growth in the manufacturing sector-no signs of a tendency towards stagnation in productivity terms.

When we turn to the development of capital productivity, the following picture emerges (see Fig. 2). While in several countries capital productivity fell at the beginning of the period of observation and in Japan even until around 2005, in all countries, again with the exception of France, the trend of capital productivity was persistently upwards. In France the growth rate of capital productivity came down from about 4 per cent to zero.

The manufacturing sector thus shows no signs of a slackening of its technological dynamism — on the contrary. While technical progress in all countries was labour saving throughout the period under consideration, and in many countries at an accelerating speed, the overall trend was also capital saving at an accelerating speed. 


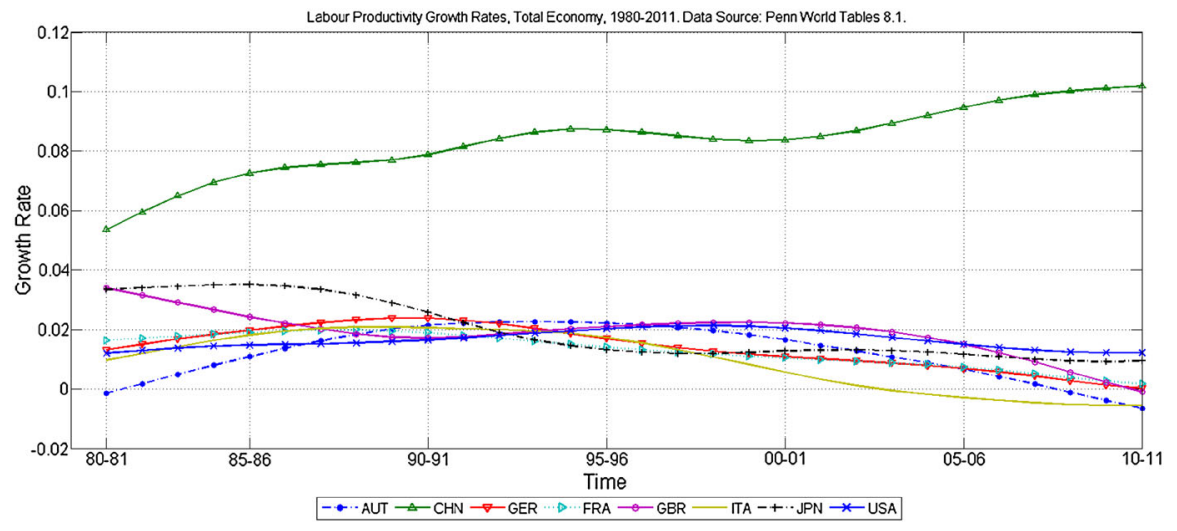

Fig. 3 Labour productivity growth in the economy as a whole

When we turn to the economy as a whole, the picture changes. Figure 3 plots the development of total labour productivity during the much longer period of 1980-2011. Several countries (Austria, Italy, USA, Germany) exhibit first an upward trend, which peaks at different points in time after 1990, and then turns downward. An exception is catching-up China, where the level of labour productivity growth is very high and the trend dominantly upwards. In Japan and Great Britain the trend is dominantly downwards, in Great Britain even more so than in Japan. A cursory glance at the diagram might be taken to support the idea that several countries are in the final phase of a long wave of economic development, with the 1980s and early 1990s showing parts of the upswing phase and the time thereafter the downswing phase. The question, however, is whether our measurement devices provide us with a sufficiently accurate picture of what is happening or are seriously misleading as several economists emphasize. In the case in which these devices are unable to capture the situation after the second digital revolution and systematically underrate outputs and partly also inputs, any nervousness about actual economic trends appears to be misplaced: it should rather be directed at the way we measure and how our statistics are compiled. The question is: Do we systematically underrate the magnitude giving the numerator in the expression of overall labour productivity and perhaps also the denominator? And if we had better measurement devices, what would we see?

Figure 4 gives the growth rate of overall capital productivity. The interesting fact here is that for many countries (Germany, Japan, France, Italy, Austria) and for most of the years under consideration capital productivity decreased, which means that the overall capital-output ratio increased. The inverse of the capital-output ratio is what may be called the maximum rate of profits, that is, the rate corresponding to hypothetically zero wages.

The kind of technical change that gives rise to a falling maximum rate of profits was first discussed by David Ricardo (1951) in the famous chapter "On Machinery", published in the third edition of his Principles of Political Economy, as an important possibility. In his "law" of the tendency of the rate of profits to fall Marx 


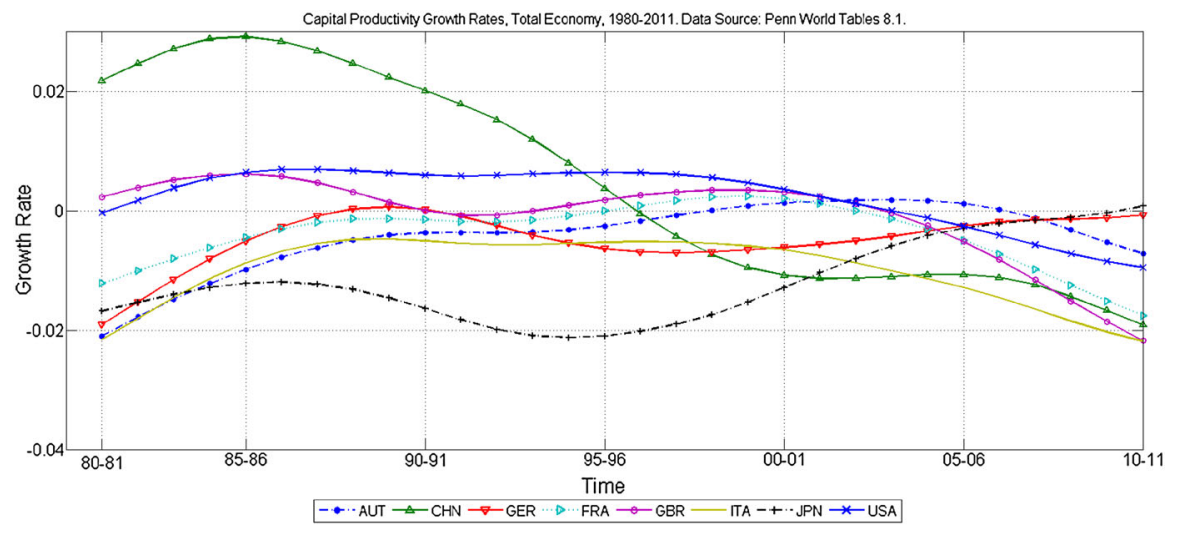

Fig. 4 Capital productivity growth in the economy as a whole

contended that this form of technical progress can be expected to dominate capitalist development, because it is congenial to the capitalist mode of production. His reasoning was not conclusive and has given rise to heated controversies that need not concern us here. It suffices to point out that several studies in more recent times insisted that the past few decades exhibited what was called "Marx-based technical progress" (see, for example, Foley and Marquetti 2002), reflected in a growing labour productivity and a rising capital-output ratio. Such a constellation is also at the centre of Piketty's recent book (2014).

The statistics displayed in the above provide a varied picture of the development in several countries. Do they support Phelps' contention of a vanishing dynamism of Western economies? I wonder.

\section{Concluding Remarks}

It has been argued in this note that the problems affecting our societies and economies at present are not so much the result of a mysterious disappearance of inventiveness and imagination of the people in developed Western economies, as Phelps deplores. It is rather the dramatic change of the socio-economic order propelled by the neoliberal ideology war that managed to capture the minds of many people and dominated politics in basically all capitalist countries. This led to a deregulation of financial markets that was partly responsible for the "great recession" and the stifling of innovative activities. But there is also the problem of a mismatch between our measurement devices and what is to be measured in a world of bits and bytes. There is reason to presume that the conventional devices tend to underestimate what is going on in terms of productivity increases. Finally, given the firm establishment and growth of an $R \& D \& I$ industry in all Western economies the talk about a declining innovativeness ought to be received with suspicion. New materials and rare earths, biotechnology, further advances in ICT and what is called 
the fourth industrial revolution based on cyber-physical systems can be expected to have important impacts on the world in which we live.

Acknowledgment Open access funding provided by University of Graz.

Open Access This article is distributed under the terms of the Creative Commons Attribution 4.0 International License (http://creativecommons.org/licenses/by/4.0/), which permits unrestricted use, distribution, and reproduction in any medium, provided you give appropriate credit to the original author(s) and the source, provide a link to the Creative Commons license, and indicate if changes were made.

\section{References}

Foley, D., \& Marquetti, A. (2002). Productivity, employment and growth in European Integration. Metroeconomica, 50(3), 277-300.

Keynes, J. M. (1936). The general theory of employment, interest and money. London: Macmillan.

Kurz, H. D. (2010). On the dismal state of a dismal science? Homo Oeconomicus, 27(3), 369-389.

Kurz, H. D. (2016). Economic thought: A brief history. New York: Columbia University Press.

Kurz, H. D., \& Salvadori, N. (1998). Endogenous growth models and the "Classical" tradition. In H. D. Kurz \& N. Salvadori (Eds.), Understanding, "Classical” economics (pp. 66-89). London: Routledge.

Phelps, E. S. (2016). What Is wrong with the west's economies? Homo Oeconomicus, 33(1), 3-10.

Piketty, T. (2014). Capital in the $21^{\text {st }}$ century. Cambridge: Harvard University Press.

Ricardo, D. (1951). The works and correspondence of David Ricardo, edited by P. Sraffa with the collaboration of M.H. Dobb (Vol. I). Cambridge: Cambridge University Press.

Romer, P. (1994). The origins of endogenous growth. Journal of Economic Perspectives, 8, 3-22.

Romer, P. (2015). Mathiness in the theory of economic growth. American Economic Review: Papers \& Proceedings, 105(5), 89-93.

Schumpeter, J. A. (1912). Theorie der wirtschaftlichen Entwicklung. Berlin: Duncker \& Humblot.

Schumpeter, J. A. (1934). The Theory of Economic Development, translation of the second edition of Theorie der wirtschaftlichen Entwicklung. Cambridge: Harvard University Press.

Smith, A. (1976a). The theory of moral sentiments (1st edition 1759). In A. L. Macfie \& D. D. Raphael (Eds.), The Glasgow Edition of the Works and Correspondence of Adam Smith. Oxford: Oxford University Press. (Cited as TMS, page number).

Smith, A. (1976b). An inquiry into the nature and causes of the wealth of nations, volumes I and II (1st edition 1776). In R. H. Campbell \& A. S. Skinner (Eds.), The Glasgow Edition of the Works and Correspondence of Adam Smith. Oxford: Oxford University Press. (Cited as WN, book number, chapter number, passage number).

Weitzman, M. (1998). Recombinant growth. Quarterly Journal of Economics, 113, 331-360. 